\title{
3D Virtual Gallery Modelling Combining Photo Panorama for Information Media Hindu Buddha Temple in West Java
}

\author{
Ayung Candra Padmasari, Asyifa Imanda Septiana, Asep Herry Hernawan
}

\begin{abstract}
The need for innovative media in the Industrial Revolution 4.0 era become a new necessity and challenge especially looking at cultural and historical potential which must remain preserved along with the times and technology. Designing new media previously designed conventionally related to historical information on West Java about Hindu Buddha Temples become a new innovation to create information media for digital age. Historical information on Hindu Buddhist temples is basically very interesting learning to be known by everyone, both teenage children and the general public, because the history of Hindu Buddhist temples includes sacred buildings from Indonesian classical relics that are used as a place of worship by historical society of Hindu Buddha. This research aims to design a $3 D$ gallery design combining photo panorama as an innovation media in conveying information related to the history of Hindu Buddhist temples. The method used in this research is Design and Development $(D \& D)$. The results of this study are $3 D$ modelling and photo assets. The texturing object was produced from 9 photos and 1 panoramic photo with the aim of displaying a realistic visualization of a $3 D$ gallery to display an interesting interior photo of the Hindu Buddha Temple.
\end{abstract}

Keywords: Gallery, Panorama, Photo, Virtual 3D.

\section{INTRODUCTION}

The need for innovative media in the era of the Industrial Revolution 4.0 becomes a necessity and new challenges especially seeing the cultural and historical potential that must remain preserved in line with the times and technology [1]. One topic that is a challenge is the information media model that was previously conventionally designed to display information, especially in the field of history, both pure science and history for learning media. The knowledge of Hindu Buddhist temples is basically a very interesting knowledge and must be known by everyone, both teenage children and the general public, because the history of the Hindu Buddhist Temple is a sacred building from Indonesia's classical relics used as a place of worship by Hindus and Buddhists.

Berta (2013), explained in his journal entitled Making a 3D Viewer Mobile Application by Using Virtual Reality Technology the rapid technological development from time

Revised Manuscript Received on January 5, 2020.

Ayung Candra Padmasari, Pendidikan Multimedia Department, Universitas Pendidikan Indonesia, Bandung, Indonesia.

E-mail: ayungcandra@upi.edu

Asyifa Imanda Septiana, Software Engineering, Universitas Pendidikan Indonesia, Bandung, Indonesia. E-mail: asyifa@upi.edu

Asep Herry Hernawan, Teknologi Pendidikan, Universitas Pendidikan Indonesia, Bandung, Indonesia. E-mail: asepherry@upi.edu to time makes it easier for humans to do some of their activities [2]. In computer graphics technology, generally what is known is $2 \mathrm{D}$ (two dimensions) for example pictures, posters, advertisements and photos that are often viewed on the internet or mass media so that the information obtained from inside is less in-depth. After passing through the $2 \mathrm{D}$ era, technology now enters the $3 \mathrm{D}$ era where the information displayed uses 3D (three dimensions): the visualization of an object or object becomes clearer (follows its original form) and is well understood. In this case the author meant is the visualization of a building or building. Gallery itself is a term that comes from English, which means a place to display or exhibit a work of art. The gallery is an exhibition where the exhibition is an activity to introduce products, works or ideas to the general public. For example, book exhibitions, writings, paintings and so on. This research emphasizes efforts to preserve the local historical heritage of West Java. Historical heritage can be regarded as a cultural preservation. Law No. 11 Year 2010 explains that the Preservation of Cultural Heritage is based on the results of a feasibility study that can be accounted for academically, technically, and administratively [3]. So, it can be said that technology products are needed now not only to answer the challenges of the industrial revolution 4.0 but also to develop historical insights so that they can be realized and visualized in more innovative variations. The example development of this research is implementation of the Virtual Tour concept began to develop in several fields including architecture. This Virtual Tour has been used extensively as an effective promotional tool especially in the field of tourism through interactive media [4], and 3D interactive simulation system (3DISS) using multimedia application authoring platform for landscape planning support system [5]. The use of virtual $3 \mathrm{D}$ galleries combining panoramic photos can be one way to increase comfort in the process of interaction between humans and machines, even more so if the interaction model is presented on a 3-dimensional basis. The history of a temple in Indonesia is inseparable from the history of a kingdom, because the construction of temples in the past was at the behest of a king or head of government who controlled the area where the temple was located. For centuries, since the Dutch colonial era, almost no ancient heritage buildings have been found in West Java [6]. Relics of the past that were used as a foothold in an effort to explain in harmony the history of the kingdoms in West Java, especially the Hindu and Buddhist kingdoms, all this time in the form of

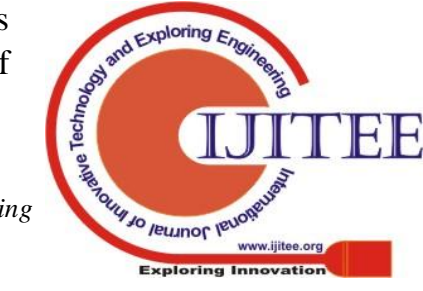


inscriptions found in several places and ancient books, such as Jawadwipa Library, Rajyarajya Bhumi Nusantara Library, and Chu-fan-chi by Chau Ju-kua (1178-1225) which is a Chinese (book) note that contains a description of Sundanese. (National Library of Indonesia) [7].

Although West Java is recorded as an area in Indonesia which has quite a number of temples, in general, people in West Java do not pay much attention or even do not look after historical relics. Some temple buildings in West Java province were made by the government as tourist destinations. Some of the many temple buildings that have been eroded by the changing times of an increasingly modern era. The following is a list of temple names in the province of West Java:

1. Bojong Menje (Rancaekek) Temple.

2. Cangkuang Temple (Garut).

3. Soul Temple (Karawang).

4. Batujaya Mosque (Talun Village).

5. Blandongan Temple (Gunteng Village).

6. Tanggulun Temple (Cianjur).

7. Serut Temple (Karawang).

8. Candi Sumur (Segaran IX).

9. Batu Kalde Temple (Pangandaran).

\section{MATERIAL AND METHODS}

Referring to the purpose of this study, namely designing a 3D Virtual Gallery, the research design used is D\&D research has two characteristics [8], namely to produce:

a. Products in the form of artefacts; and products are produced through a research process. The D\&D Research implementation involves 3 stages, illustrated as follows:

b. Market or Costumers (Potential and problems needed or needs needed).

c. Production (Producing Product Design).

d. Design and Development.

Interface design with virtual roaming methods is done by changing the event results from the mouse and keyboard by initializing each command into the data as a navigation control.

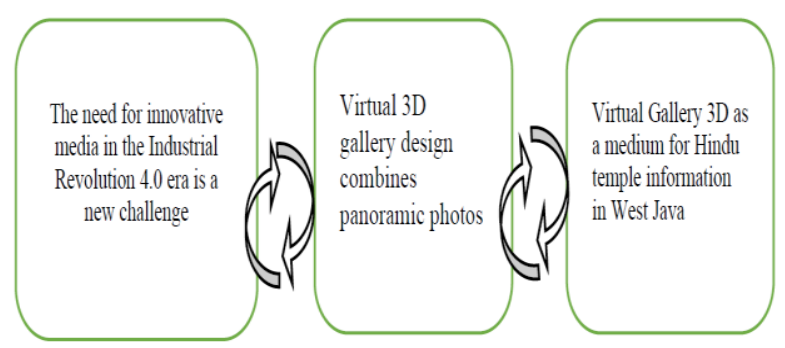

Fig. 1. Design and Development Methode flow.

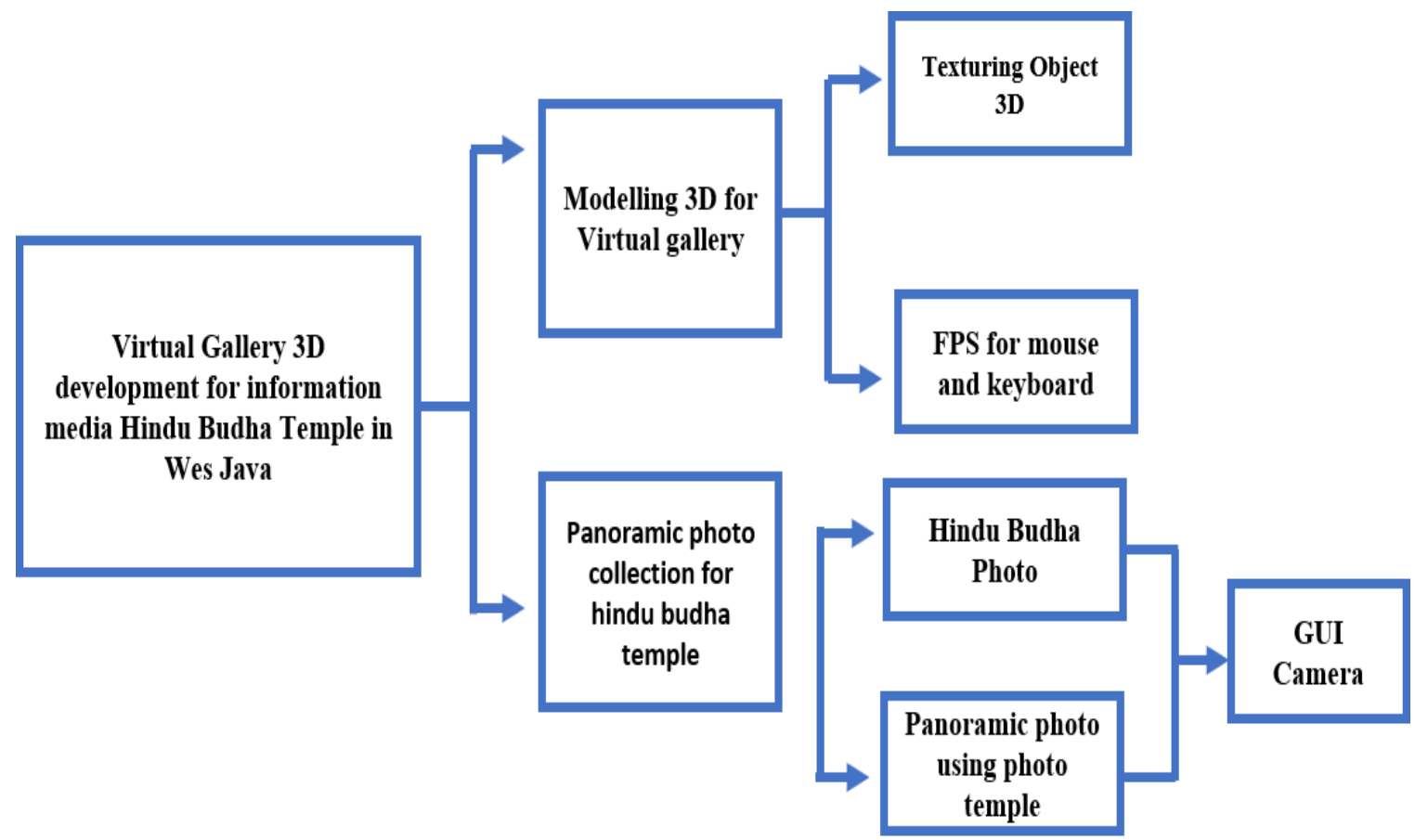

Fig. 2. Flowchart modelling 3D. 


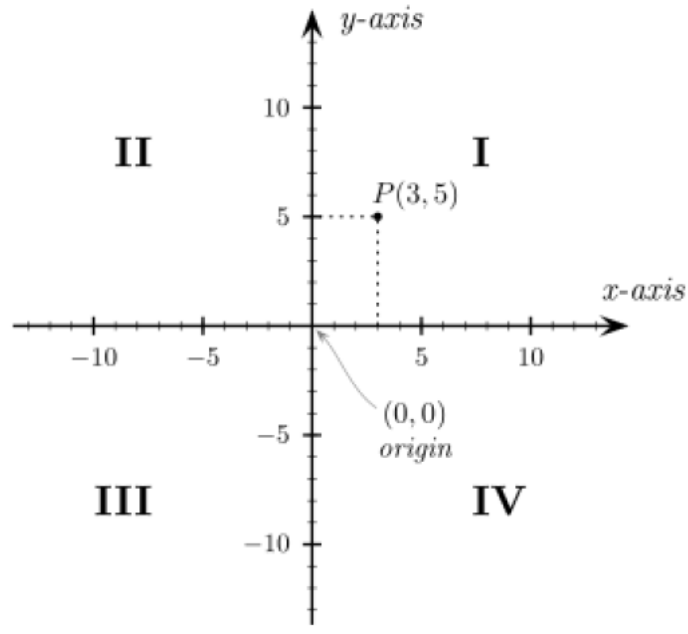

Fig. 3. Kartesius coordinates for the design of the button position in the Unity 3D camera.

Spatial design is designed by using Corel Draw as a reference in making 3-dimensional space designs. Figure 2 is a visualization of space design consisting in 2 dimensions consisting of storage space photographs of West Java temple. Navigation control scenario for 3D virtual gallery The GUI on the Unity 3D camera is used to assist users in selecting buttons for the menu display that has been provided. Some designs such as intros enter the space in the initial display and navigation in the application requires several buttons as a tool in controlling and selecting the interactions provided. Researchers utilize the Cartesian coordinate system in two dimensions which are generally defined by two axes that are perpendicular to each other and located on one plane "Fields $\mathrm{X}$ and $\mathrm{Y}$ " (Figure 3).

\section{RESULTS AND DISCUSSION}

\section{A. Material and Texture Modelling}

Designing objects in 3D is done with the aim of creating models and visualizations that resemble real. 3D modelling is a term of the concept and design process that is shown as a whole in three dimensions, there are several aspects to consider when building an object model, all of which contribute to the quality of the final result. These include methods for obtaining or creating data that describe objects, the objectives of the model, level of complexity, cost calculation, suitable and comfortable, and easy of models manipulation. These results are sometimes displayed in real time for simulation purposes. In general, the principle used is similar to 2D objects, in terms of: the use of algorithms, vector graphics, wire frame models, and raster graphics [9]. The following is the initial design modelling for the visualization of the $3 \mathrm{D}$ gallery building as a storage for Hindu Buddha temples (Figure 4).

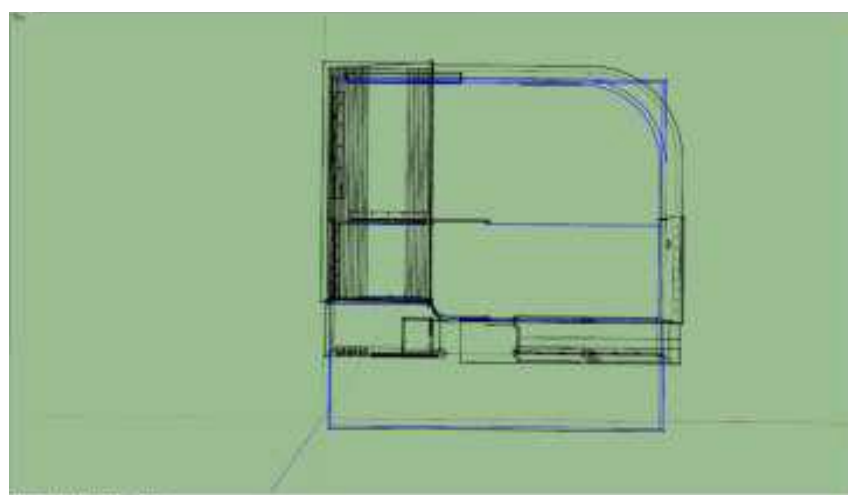

Fig. 4. Figure Header.

In the stage of making 3D modelling for the virtual design the Maps texture method is done by realizing 2D images that are poured on the surface of the geometry or object to make the appearance of the object appear to have a texture effect. The process of applying textures like this is categorized as a method for adding surface texture details (bitmaps or raster images), and colour effects generated by computer graphics for 3D models. The normal mapping technique for applying textures is usually accuracy as an RGB image that is related to the $\mathrm{X}, \mathrm{Y}$, and $\mathrm{Z}$ coordinates of the normal surface of an object. Normal map is a texture that is used to give the impression of the depth of detail of an object without having to create objects with a large number of poly, so that the impact on the efficiency of computer work without having to lose the desired details. There are several techniques used in the process of making textures for virtual modelling of this gallery, including the methods, the Normal mapping stage, Environment maps, Bump maps, and Shadow maps. The first stage is making the initial model of spatial dimensions in the form of a floor plan in the form of wireframes. The initial spatial dimension design is made by utilizing a large tool set in the Sketchup facility, for space partitioning, it can be built by making a rectangle tool that utilizes a combination of 2 point arcs and 3 point arcs to set the precision of the space according to the design that has been created. X (blue), Y (red), Z (green). for the initial design can be seen in Figure 3. The next stage, create a landscape grounding on the dimensions of the gallery space that has been created, by utilizing the combination of the arc tool and pie tool functions in the $\mathrm{Z}$ (green) transformation line. In this stage, the required grounding design will be adjusted to the dimensions of space (Figure 5).

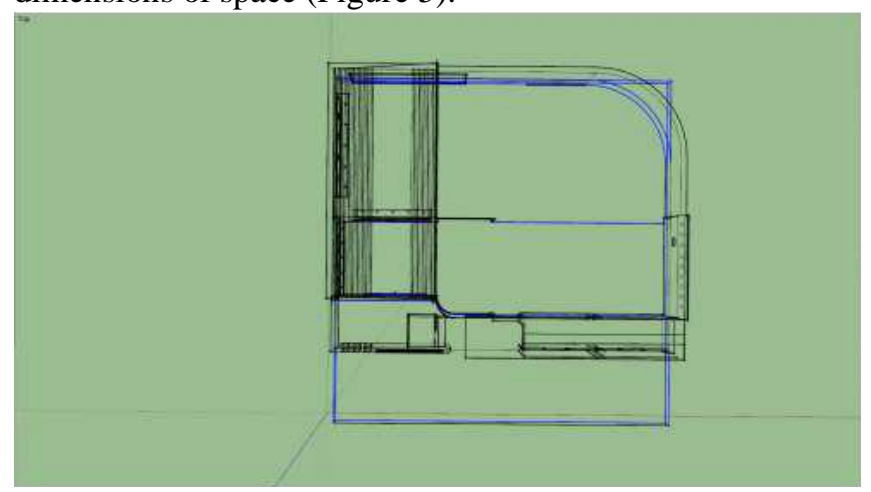




\section{Fig. 5. Landscape grounding in the dimensions of the} gallery space.

Next, create dynamic components in gallery space dimensions that already have landscape grounding, with landscape grounding, the 3D object components that are inputted on the dimensions of gallery space can be symmetrical with coordinate lines. Dynamic component utilizes a combination of the functions of the orbit tool, move tool and rotate tool in the transformation lines $\mathrm{X}$ (blue), $\mathrm{Y}$ (red), Z (green). In this stage, a dynamic component object design is made which is divided into three parts of space, including "Front area, Centre area, and Bottom area" (Figure $6)$.
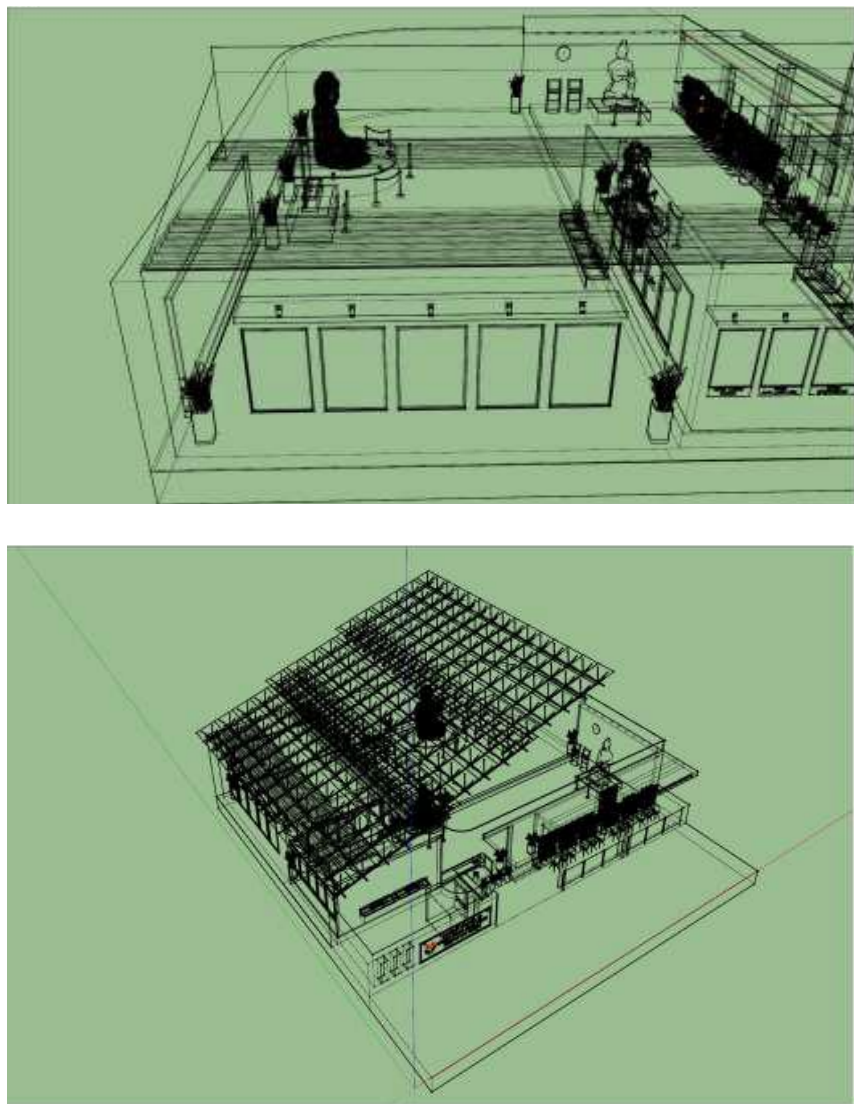

Fig. 6. Dynamic component in the bottom dimension of the gallery space.

The process of producing three-dimensional objects, modelling techniques, textures and material selection are needed. By using the appropriate engineering pattern, it will affect the details of the geometry field objects and the suitability of the model with the original shape. It should also be noted that the efficiency of memory usage and data storage media on the computer. The definition of a 3D object itself is a representation of 3-dimensional geometric data as a result of processing and providing light effects on 2D computer graphics. In designing this gallery virtual design material, researchers used the Texture Baking Workbench function in Simlab Composer 9 software as a texture processor in the virtual gallery geometry field. In addition to using the Texture Baking Workbench above, a material processing function is also needed in the geometry field, which is using the Material Tab function [10]. Various types of materials can be applied to selected geometry materials, and each tool in this Material Tab has a different effect on the appearance of three-dimensional (3D) models, thus reducing the time and complexity of the modelling required. The definition of a 3D object itself is a representation of 3-dimensional geometric data as a result of processing and providing light effects on 2D computer graphics. These results are sometimes displayed in real time for simulation purposes. In general, the principle used is similar to 2D objects, in terms of: the use of algorithms, vector graphics, wire frame models, and raster graphics [11].

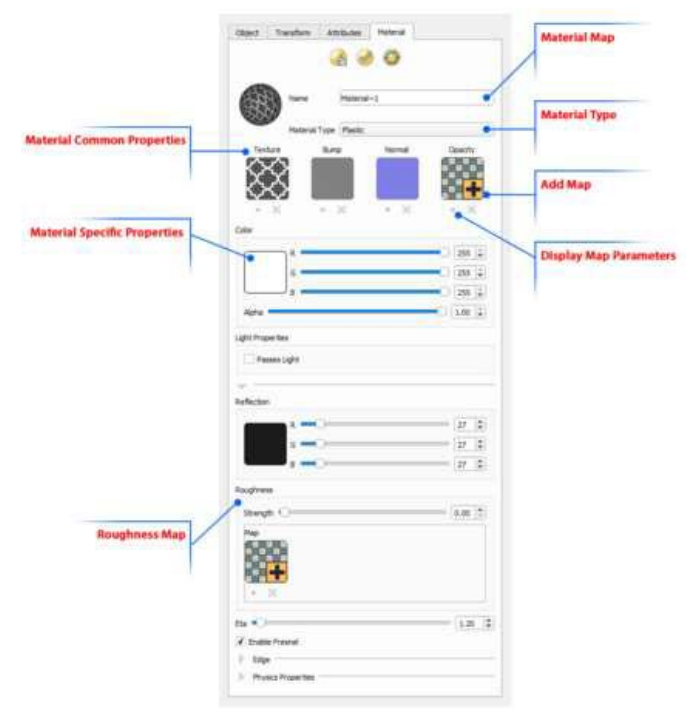

Fig. 7. Image Material Tab.

Each tool has its own parameters which can be accessed by clicking on the down arrow in the Material Common Properties. Users can add Material to the geometry field by clicking the "+" image on the Add Map. Specified material types or models can also be deleted by clicking the " $\mathrm{x}$ " button in the Material Common Properties (Figure 8).

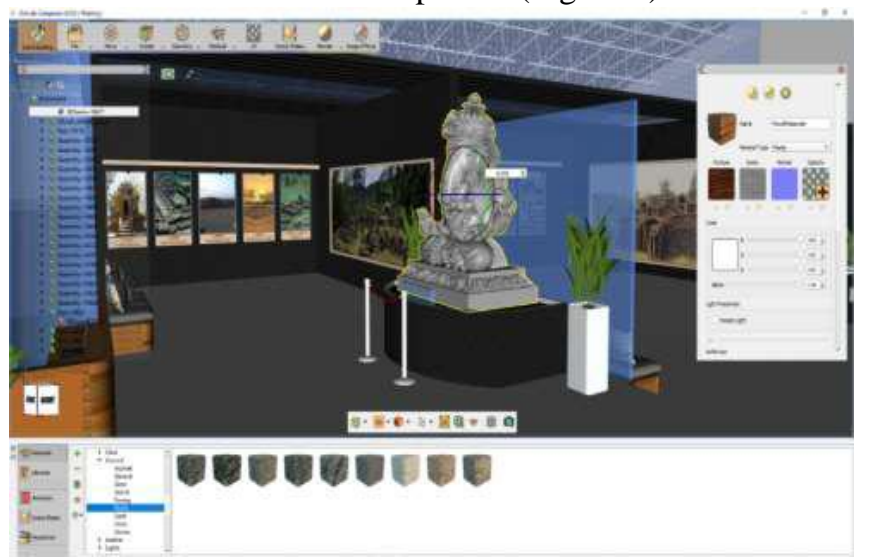

Fig. 8. The process of selecting material against the geometry plane. 


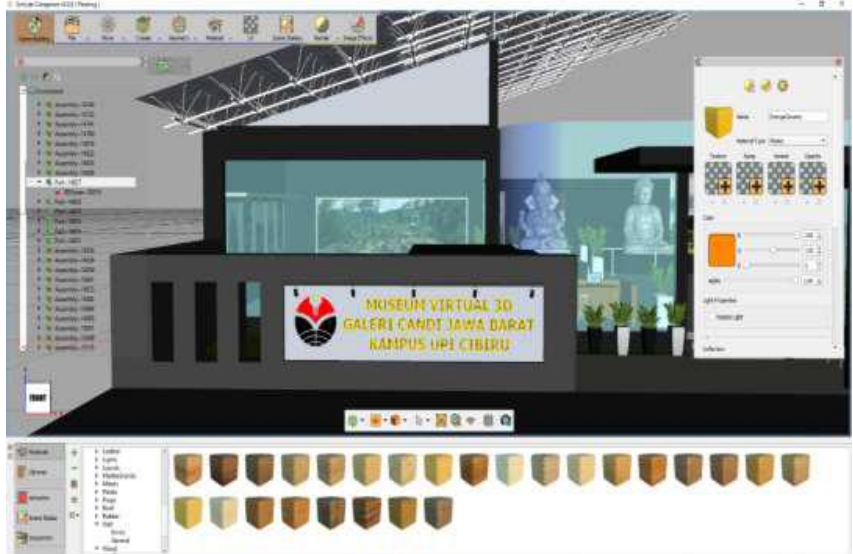

Fig. 9. The process of selecting material against the geometry plane.

\section{B. Modelling Photo Panorama}

Panorama Photo is a technique of combining several photo objects with the aim of getting a wide photo and covering a wide scene. In the mobile camera, an automatic application is available to apply the Panorama technique After activating the panorama mode, then slowly rotate the camera from left to right and let the camera combines several photos into a complete panoramic photo [12] (Figure 10).

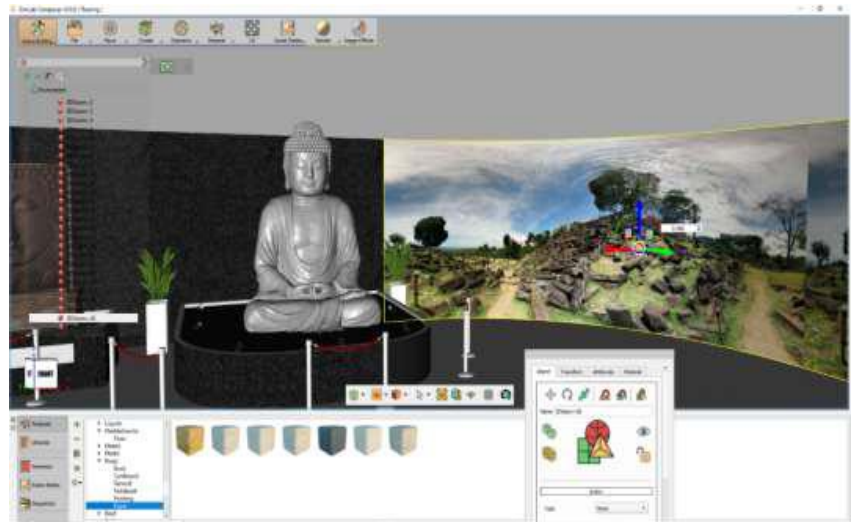

Fig. 10. Image panorama photo Gunung Padang site in West Java Indonesia.

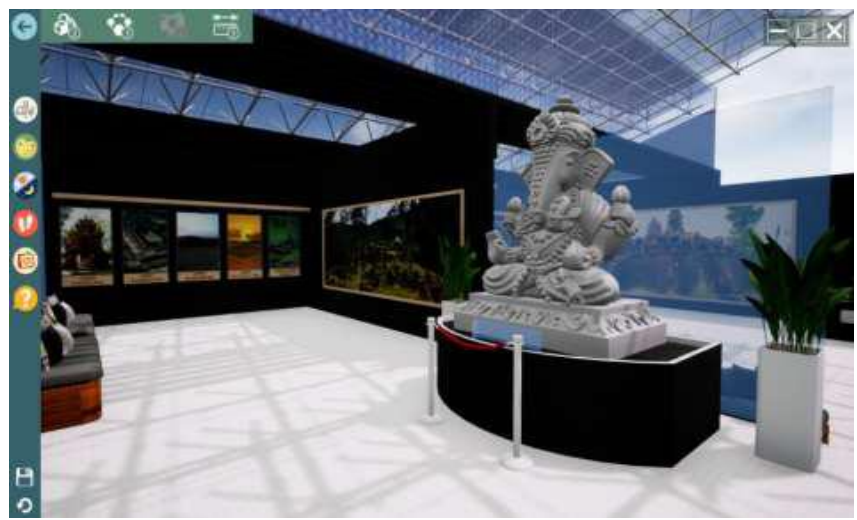

Fig. 11. Image display on virtual gallery 3D.

Interface design or user interface (UI) is a term used to describe the appearance of a machine or computer that interacts directly with the user. Schlatter (2013) provides a guide to compiling an easy to use application design by dividing it into several influential components as follows
[13]:

a. Consistency: consistency of user interface display.

b. Hierarchy: arrangement of the hierarchy of interests of the objects contained in the application.

c. Personality: first impressions seen in the application that show the characteristics of the application.

d. Layout: the layout of the elements in an application.

e. Type: typography used in an application.

f. Colour: the use of the right colour used in an application.

g. Imagery: the use of images, icons, and the like to convey information in an application.

h. Control and Affordances: elements of the user interface that people can use to interact with the system through a screen.

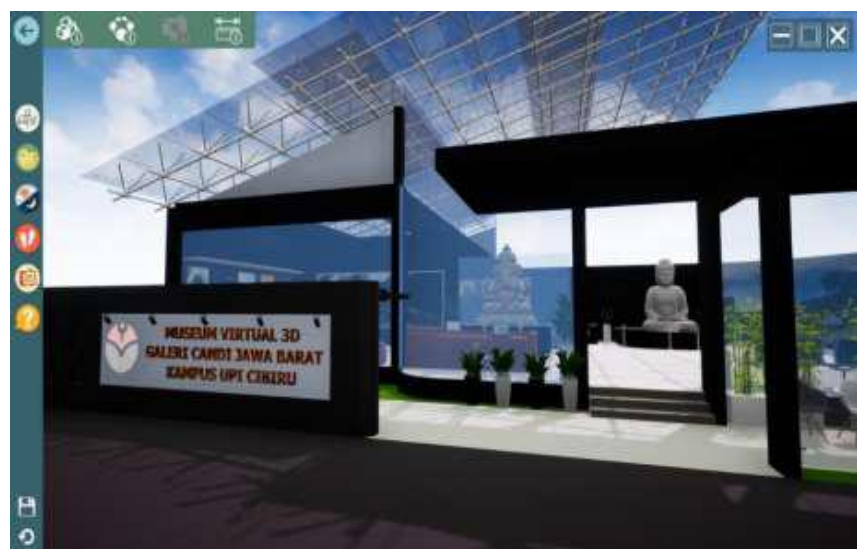

Fig. 12. The interface design or user interface (UI) on virtual gallery $3 \mathrm{D}$.

\section{CONCLUSION}

The history of a temple in Indonesia is inseparable from the history of a kingdom, because the construction of temples in the past was at the behest of a king or head of government who controlled the area where the temple was located. For centuries, since the Dutch colonial era, almost no ancient heritage buildings have been found in West Java. Relics of the past that were used as a foothold in an effort to explain in harmony the history of the kingdoms in West Java, especially the Hindu and Buddhist kingdoms, all this time in the form of inscriptions found in several places and ancient books, such as Jawadwipa Library, Rajyarajya Bhumi Nusantara Library, and Chu-fan-chi by Chau Ju-kua (1178-1225) which is a Chinese (book) note that contains a description of Sundanese. (National Library of Indonesia). Although West Java is recorded as an area in Indonesia which has quite a number of temples, in general, people in West Java do not pay much attention or even do not look after historical relics.

\section{ACKNOWLEDGMENT}

Thank you for the financial support for this research, which has been provided by a grant from Universitas Pendidikan Indonesia. Thank you, author convey to the Department of Pendidikan Multimedia Campus UPI Cibiru, for the supporting infrastructure that has been provided in this study

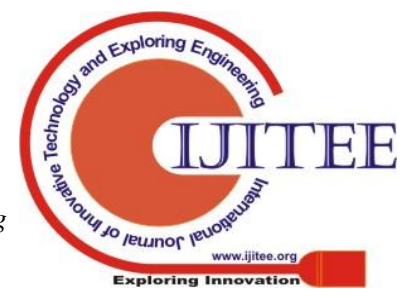




\section{REFERENCES}

1. Seftiawan, Dhita, Ini 5 Elemen untuk Hadapi Revolusi Industri 4.0. [online] Tersedia: 2018 http://www.pikiran-rakyat.com/pendidikan/2018/01/17/ini-5-elemen-un tuk-hadapi-revolusiindustri-40-418079.

2. Berta. Aplikasi $3 D$ viewer mobile dengan menggunakan teknologi Virtual Reality. Jurnal Teknik Pomits Vol. 2, No. 2, ISSN: 2337-3539 (2301-9271 Print). 2013

3. Wisnubro, Lima Elemen Penting Menjawab Tantangan Revolusi Industri 4.0.[online] 2018 https://jpp.go.id/teknologi/iptek/315273-lima-elemen-penting-menjawab -tantanganrevolusiindustri- 4-0.

4. Herry Santosa, 3D interactive simulation system (3DISS) using multimedia application authoring platform for landscape planning support system, International Conference, Intelligent Planning Towards Smart Cities, CITIES 2015, 3-4 November 2015, Surabaya, Indonesia. Procedia - Social and Behavioral Sciences 227 (2016) 247 - 254, 2015.

5. Abdulkhalyk, Virtual Reconstruction of Historical Architectural Monuments: Methods and Technologies, International Journal of Innovative Technology and Exploring Engineering (IJITEE) ISSN: 2278-3075, Volume-8 Issue-10, August 2019.

6. https://candi.perpusnas.go.id/temples_en/deskripsi-west_java.

7. https://www.worldcat.org/title/pustaka-rajya-rajya-i-bhumi-nusantara/oc lc/645721934.

8. Tether, Bruce, D\&D - design and development and alternative or complement to R\&D. Washington D.C: NCSES/CNSTAT workshop on advancing concept models of innovative activity and STI indicator systems, 2017

9. Mega Orina Fitri, Rancang Bangun Aplikasi Virtual Tour Monumen Mandala berbasis Android, Jurnal Instek Volume 1, Nomor 1. Oktober, 2016.

10. https://www.simlabit.com/blog-2/

11. Supriyadi, Interaksi Objek Animasi 3D berbasis Multimedia, Jurnal katulistiwa Informatika, vol. VI, No. 1 Juni $p-I S S N$ : 2339-1928 \& e-ISSN: 2579-633X, 2018.

12. https://informatika.uc.ac.id/2016/12/kamera-360-terbaik/

13. Schlatter, Visual Usability, Tehe Principle and practice for designing digital application, Library of Congress Cataloging- in-Publication Data, Morgan Kaufmann is an imprint of Elsevier 225 Wyman Street, Waltham, MA 02451, USA, 2013.

\section{AUTHORS PROFILE}

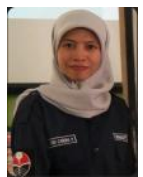

Ayung Candra Padmasari, Graduates Of Jaringan Cerdas Multimedia Concentrating Game Technology at The Sepuluh Nopember Institute Of Technology (ITS) Surabaya. Now A Lecturer At Universitas Pendidikan Indonesia.

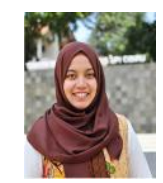

Asyifa Imanda Septiana, Graduates Of Information, Production And System, Waseda University, Japan, And Currently A Lecturer at Universitas Pendidikan Indonesia.

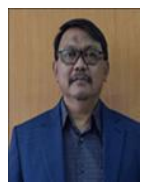

Asep Herry Hernawan, Curriculum And Educational Technology Expertise And Become A Lecturer In The Education Technology Of Universitas Pendidikan Indonesia. 